\title{
Understanding the Independent Dancer: Roles, Development and Success
}

RACHEL FARRER AND IMOGEN AUJLA

Little research has been published about the varied role of the independent dancer. The aim of this study was to provide insight into the work independent dancers undertake and how their careers change over time. Semi-structured interviews were conducted with 14 independent dancers. Content analysis revealed that the dancers had multifaceted careers that relied on both formal and informal activities, and varied according to three distinct stages (early, middle, late). The experiences reported by the dancers indicated that the realities of the independent dancer's role are not sufficiently recognised or supported within the industry.

Keywords: Independent dance, dancer, roles, networks

\section{INTRODUCTION}

The term 'independent dancer' is becoming increasingly popular to describe those working in the UK dance industry in multiple roles on a freelance basis (Clarke 1993; Farrer 2014; Roche 2009). In the past, labels such as dance animateur and community dance artist have been used to denote individuals working in community and educational settings, and terms including freelance dancer or portfolio artist, used to describe performers or choreographers. It has become increasingly difficult to distinguish between these formal labels however, and the term independent dancer is now more commonly used for individuals who encompass all or some of these roles, and many more. The organisation Independent Dance began to operate under this name in 1992, acting as a centre to support and nurture independent dancers, and raise the profile of their work. Since this development there have been a limited but growing number of sources reporting on the sector including Arts Council documents (1998), magazine interviews with independent dancers (Rubidge 1993) and academic

Dance Research 34.2 (2016): 202-219

Edinburgh University Press

DOI: $10.3366 /$ drs.2016.0159

(C) Society for Dance Research

www.euppublishing.com/drs 
research in the field (Aujla, Farrer 2015; Hawksley 2012; Farrer 2014; Roche 2009; Rouhiainen 2003). These sources suggest that the sector has continued to grow over the last 20 years and indicate a sustained concern and interest in what independent dancers do. It is estimated that around 40,000 people work in the UK dance industry; however, the varied and ad hoc nature of those working in freelance capacities makes it challenging to accurately describe the activity they undertake (Burns, Harrison 2009). Therefore, the aim of the current study was to provide up to date information about what independent dancers do and how their careers develop over time.

In 1997, Clarke defined the independent dance sector as:

$[\mathrm{A}] \mathrm{n}$ extensive and mobile community of independent dance artists in the UK, with the largest concentration based in London. Through choice or necessity these dance artists work as freelance entrepreneurs, often juggling many roles simultaneously and taking their expertise into numerous communities through their performance, choreography, teaching and facilitation.

(Clarke 1997)

This definition was supported by the Independent Dance Review Report (Clarke and Gibson 1998) which consulted 460 people to provide details about the range of work that independent dancers do, including information about their backgrounds and experiences; the content of their work; and their employment conditions, such as working hours, contracts and rates of pay. The review demonstrated how those working in the sector assumed a range of roles, including performance, choreographic, teaching and arts administration roles. They generally experienced 'sporadic' patterns of employment, having no clear career prospects, no sense of progression and low wages (1998). Despite these hardships, Clarke and Gibson recognised the value in working independently and proposed measures that could support and facilitate work of this kind including fair pay, mentorship, training and development opportunities focusing particularly on 'complementary skills' such as promotion, production and administration (1998, 15), support and opportunities provided by Dance Agencies or performing arts venues, and the sharing of resources and management (1998).

The Independent Dance Review Report (1998) concluded with a proposed 'new model' which called for changes in funding, infrastructure and attitudes towards the sector. Since its publication, however, there has been little formal evidence of information being gathered about these concerns or any monitoring of the new proposals that Clarke and Gibson advocated. Where it has been undertaken, research into the field has focused specifically on choreographic concerns around creativity, collaboration and authorship (Roche 2009; Farrer 2014; Butterworth 2009; Bannerman, McLaughlin 2009) or is situated within a different geographical location, such as Rouhiainen's study of Finnish freelance dancers (2003). Thus, it is necessary to update knowledge about the work UK independent dancers are doing in order to understand how current working conditions are shaping and informing their practice. This study aims to update the examined literature by providing descriptions of independent dancers' work 
based on primary evidence collected from those currently working in the sector. The study seeks to pool the experiences of 14 independent dancers in order to identify common practices and identify emerging themes of interest. It will explore the perceptions of those working in the sector, to provide a realistic account of the work independent dancers do. This will help researchers, educators and funders to better provide for and support those undertaking such roles. Further knowledge about the sector could also prompt a shift in the way those who are engaging with it are valued.

\section{METHOD}

\section{Participants}

In total, 14 dancers took part in the study, 11 female and three male. The average age of the participants was $32.4( \pm 6.05)$ and their ages ranged from 22-42 years. Participants were recruited via a web callout made by an independent dance organisation based in London. This meant that although participants came from a range of geographical locations within the UK, the majority were based in London or the South East. The call targeted a broad range of dancers working within the sector with the criteria for inclusion being that participants identified themselves as independent dancers. As it is relevant for the discursive nature of this article, Table 1 details information about the participants' backgrounds, experiences and current roles, to provide a context for the results. This information begins to indicate the breadth of work that independent dancers are undertaking in multiple contexts, and illustrates their varied pathways into the sector. In order to protect the participants' anonymity, pseudonyms have been used.

\section{Procedure}

Prior to data collection, ethical approval was sought from a higher education ethics committee agreeing that all participants would provide informed consent in order to take part in the research. Participants were met at convenient times and locations for face-to-face interviews that lasted between 35 and 70 minutes. Three of the interviews were conducted via Skype due to travel restrictions and childcare needs. The first author undertook all interviews and they were recorded using a dictaphone. Participants were firstly informed about the nature of the project and the procedure of the interview. They were invited to request clarification about any questions they did not understand and assured that they could decline to answer anything they preferred not to discuss. A semi structured, open-ended interview guide (Patton 2002) was developed based on existing literature and the overarching research questions. The interview began with general questions about the participants' backgrounds, training and transitions into the sector, followed by more pragmatic questions about their working hours and roles, and what their experience of this was. Finally participants were asked questions that related to how they perceived their role and defined success. 
Table 1.

\begin{tabular}{|c|c|c|c|}
\hline Pseudonym & Age & Background & Current role/s \\
\hline Robert & 31 & $\begin{array}{l}\text { Undertook dance training at } \\
\text { a university in Germany and } \\
\text { experienced working in Dance } \\
\text { Theatre. }\end{array}$ & $\begin{array}{l}\text { Working to establish himself as } \\
\text { a choreographer in London. }\end{array}$ \\
\hline Louise & 30 & $\begin{array}{l}\text { Undertook contemporary } \\
\text { dance training at a vocational } \\
\text { school. }\end{array}$ & $\begin{array}{l}\text { Works across disciplines, often } \\
\text { collaboratively with other } \\
\text { artists or organisations } \\
\text { in a range of movement based } \\
\text { roles eg. movement director or } \\
\text { dramaturge. Based in London. }\end{array}$ \\
\hline Jenny & 22 & $\begin{array}{l}\text { Undertook contemporary } \\
\text { dance training at a university. }\end{array}$ & $\begin{array}{l}\text { Trying to establish herself as } \\
\text { an independent artist engaging } \\
\text { with small choreography and } \\
\text { performance projects and } \\
\text { undertaking teaching roles. } \\
\text { Based in the South East. }\end{array}$ \\
\hline Mary & 27 & $\begin{array}{l}\text { Undertook contemporary } \\
\text { dance training at a university. }\end{array}$ & $\begin{array}{l}\text { Works part time lecturing at } \\
\text { a university and part time } \\
\text { within freelance teaching and } \\
\text { performance contexts. Based in } \\
\text { London. }\end{array}$ \\
\hline Anne & 31 & $\begin{array}{l}\text { Undertook contemporary } \\
\text { dance training at a university } \\
\text { and vocational settings. }\end{array}$ & $\begin{array}{l}\text { Had previously worked } \\
\text { freelance predominantly as a } \\
\text { performer and now had a } \\
\text { fixed-term performance } \\
\text { contract with an integrated } \\
\text { dance company. Based in } \\
\text { London. }\end{array}$ \\
\hline Sally & 26 & $\begin{array}{l}\text { Undertook contemporary } \\
\text { dance training at a university. }\end{array}$ & $\begin{array}{l}\text { Works in a freelance capacity } \\
\text { for several choreographers and } \\
\text { has own choreographic projects } \\
\text { funded. Based in the North } \\
\text { West. }\end{array}$ \\
\hline Jane & 40 & $\begin{array}{l}\text { Undertook contemporary } \\
\text { dance training at a vocational } \\
\text { school. }\end{array}$ & $\begin{array}{l}\text { Had previously worked as a } \\
\text { performer for professional } \\
\text { companies, and now undertook } \\
\text { own project work as a } \\
\text { choreographer. Based in the } \\
\text { South East. }\end{array}$ \\
\hline Jeanne & 46 & $\begin{array}{l}\text { Undertook contemporary } \\
\text { dance training at a university. }\end{array}$ & $\begin{array}{l}\text { Runs an arts organisation as } \\
\text { well as undertaking project } \\
\text { roles as a choreographer and } \\
\text { teacher and is undertaking an } \\
\text { MA. Based in the South East. }\end{array}$ \\
\hline
\end{tabular}


Table 1. Continued.

\begin{tabular}{|c|c|c|c|}
\hline Aiden & 30 & $\begin{array}{l}\text { Undertook training in } \\
\text { commercial dance at a } \\
\text { vocational school before taking } \\
\text { an apprenticeship with a major } \\
\text { contemporary company. }\end{array}$ & $\begin{array}{l}\text { Works as a choreographer as } \\
\text { well as performing for other } \\
\text { companies. Based in London. }\end{array}$ \\
\hline Leigh & 27 & $\begin{array}{l}\text { Undertook vocational training } \\
\text { in a range of dance styles } \\
\text { including contemporary and } \\
\text { commercial. }\end{array}$ & $\begin{array}{l}\text { Works predominantly as a } \\
\text { performer for other } \\
\text { choreographers, and } \\
\text { undertakes some teaching roles. } \\
\text { Based in the South East. }\end{array}$ \\
\hline Patrick & 41 & $\begin{array}{l}\text { Undertook vocational } \\
\text { contemporary dance training } \\
\text { and experienced working full } \\
\text { time in a professional dance } \\
\text { company. }\end{array}$ & $\begin{array}{l}\text { Had previously worked as a } \\
\text { performer for professional } \\
\text { companies, and now } \\
\text { undertakes own project work } \\
\text { as a choreographer. Based in } \\
\text { London. }\end{array}$ \\
\hline Stephanie & 34 & $\begin{array}{l}\text { Trained to be a primary school } \\
\text { teacher at a university before } \\
\text { undertaking a vocational MA } \\
\text { course. }\end{array}$ & $\begin{array}{l}\text { Works predominantly } \\
\text { in an education setting and } \\
\text { undertakes small performance } \\
\text { projects when able to. Based in } \\
\text { London. }\end{array}$ \\
\hline Claire & 42 & $\begin{array}{l}\text { Undertook contemporary } \\
\text { dance training at a university. } \\
\text { Experienced working with a } \\
\text { circus group in early career. }\end{array}$ & $\begin{array}{l}\text { Has her own children's theatre } \\
\text { company as well as working } \\
\text { freelance on other projects. } \\
\text { Based in the South West. }\end{array}$ \\
\hline Alice & 36 & $\begin{array}{l}\text { Undertook contemporary } \\
\text { dance training at a university. }\end{array}$ & $\begin{array}{l}\text { Worked predominantly as a } \\
\text { performer with small } \\
\text { companies. Had recently taken } \\
\text { time off work to have a baby. } \\
\text { Based in the East Midlands. }\end{array}$ \\
\hline
\end{tabular}

\section{Analysis}

The interview recordings were transcribed verbatim and NVivo 10 qualitative analysis software was used to code them. Throughout the interview stage, the transcription and initial coding took place simultaneously (Charmaz 2006) to allow the researcher to find a saturation point where no new information was emerging (Patton 2002). All of the transcripts were coded by the first author, and the second author independently coded $15 \%$ of the transcripts to ensure agreement and parity between the researchers (Creswell and Miller 2000).

The analysis process was inductive, in order to explore the data without imposing pre-existing expectations on it (Patton 2002). During the simultaneous coding and interview stage, the data were coded into meaning units and these were used to build lower order themes. The authors began the process of ordering the codes into higher order themes together, before evaluating the 
data independently and then reconvening to discuss and debate their labels and hierarchies. To further ensure validity, the initial data analysis was reviewed during a peer debriefing process (Creswell, Miller, 2000), in which industry experts, familiar with the area, responded to the methods and interpretations of the data. Furthermore, a member checking process was undertaken whereby all participants were invited to a focus group to hear about the research (Creswell and Miller 2000). Throughout the discussion of the findings, analysis is balanced with thick descriptions and quotes to allow the reader to have an informed understanding of the interpretations (Patton 2002). The participants are referred to by their pseudonyms to allow the reader to cross-check information in relation to the context outlined in Table 1 .

\section{RESULTS AND DISCUSSION}

The key themes that emerged from the data were: 1. What is the role of an independent dancer?; 2. How do independent dancers' careers change and develop over time?; 3. How do independent dancers understand success? These themes are represented in Figure 1 and discussed in relation to existing literature throughout the results section.

\section{What is the role of an independent dancer?}

This theme was created from questions about the participants' work including when, where and how it took place. The results formed three categories: content of work, patterns of work, and the role of networks and relationships.

\section{Content of work:}

Much like the evidence shared in previously published literature about the sector (Clarke 1997; Clarke and Gibson 1998; Rouhiainen 2003), participants described their work as being multifaceted, with dancers initiating their own work in a variety of contexts simultaneously. They described themselves as having 'portfolio' careers or 'wearing different hats'. The formal roles that the participants assumed included choreographing, performing, teaching, examining, facilitating projects and arts management. Although evidence from Aujla and Farrer (2015) suggests that variety is generally considered a positive aspect of freelance work, some dancers raised concerns about how sufficiently they could fulfil so many roles:

Lecturer in HE, primary school, I deal with dance management, I perform, I run like a local dance community group... Am I happy to be all of those things? I enjoy each of them but then it's unsettling that so many people know me as a different thing... How do I bring these things together? (Mary)

The participants also spoke about less formal activities that still contributed to their careers, but which usually took place outside of paid work time, such as administration, budgeting and accounting, continued training and 


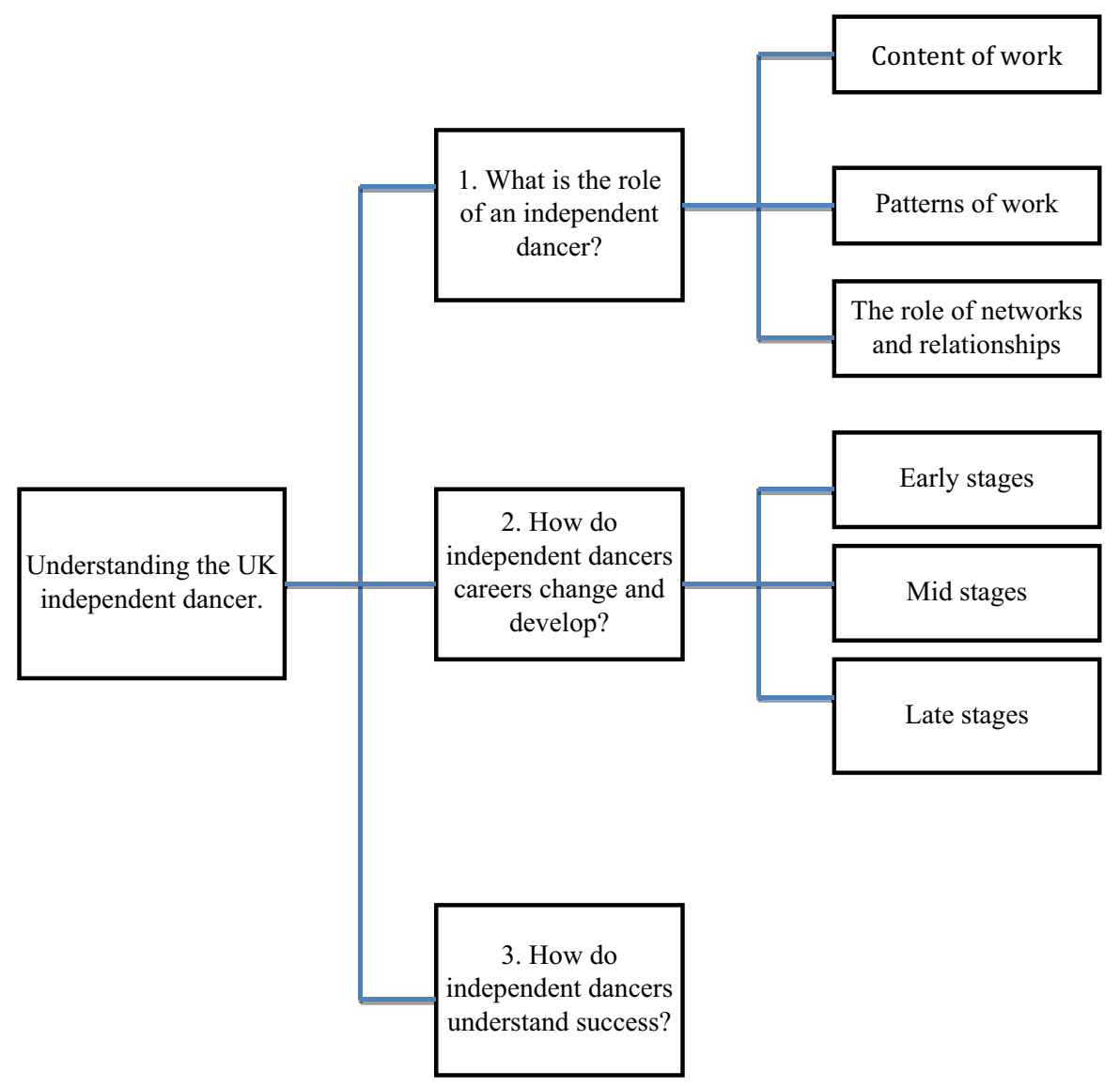

Fig. 1.

physical conditioning, networking, finding work and funding opportunities, application writing, auditioning, planning, marking and evaluating. While a number of sources (Clarke and Gibson 1998; Rouenhien 2003) have previously described independent dancers' work as 'varied', there is no existing research that specifically addresses this range of informal roles. Furthermore, many participants identified such informal activities as happening during their 'time off' or 'down time' indicating that dancers are not being sufficiently recognised or supported for the informal work they undertake:

I was really good, in my what I'd say, in my time off to actually technically still be working ... I'd be doing administration, applying to auditions, making contacts, perhaps being involved in a pre-project, going to a residency, all those kind of things. (Alice)

As well as describing a range of different dance related roles, the participants also spoke about other disciplines they had engaged with in order to find work or pursue particular interests. Some worked collaboratively with other art forms or had undertaken projects within different industries to enhance their skills. Similarly, the participants also recognised the value of taking on unpaid work 
if they felt it would satisfy their artistic needs, enhance self-development, or lead to other opportunities:

I did an unpaid job with a choreographer and she didn't really know me at the time and she had like four of us dancing but I made sure I made an effort to talk to her and I would volunteer to do stuff and then a few weeks later I got a phone call saying I'm doing another project do you want to be involved. (Sally)

Despite the range of activities that dancers spoke about they sometimes still had to take on extra non dance specific work that they would prefer not to, in order to support themselves financially. In some instances these were solely to provide financial support, however some participants undertook arts-related positions that fed into their artistic roles. The participant's experiences reflect Clarke's description of independent dancers as 'entrepreneurs' (1997) and further demonstrate the adaptable and determined nature of those working in the sector, building knowledge and experience at every opportunity.

\section{Patterns of work:}

The independent dancers had complex patterns of work and described many challenges to organising their time effectively. Unlike the 'sporadic' (1998) patterns of work that Clarke and Gibson described however, many participants in this study were able to reflect back over their work and see patterns and cycles that emerged year to year:

If I look back, I kind of go, "Oh, OK, so these people that I've worked with as a movement director have asked me back, like every six months, or every year to work with them". So there are repeated patterns with different people, there's teaching in certain places that now is becoming a little bit more regular. (Louise)

Some dancers commented upon how the structure of their year was dictated by educational cycles. In other instances, participants reflected upon how national events had informed their work patterns such as the London Olympics 2012.

Despite these recurring patterns, the participants expressed the difficulty they sometimes had in fitting their different roles around each other and ensuring that they followed on from each other throughout the year:

When you are a freelancer it's great when things work out when it finishes on a Sunday and you start the next job on a Monday and it perfectly fits. But there can be overlap and it's a bit tricky to manage. (Aiden)

As a result, some dancers described periods of unemployment that were concerning and created financial instability This meant they were reluctant to take time off work for holidays or social events in case they missed out on vital work opportunities:

You're scared if you book a holiday and an audition comes up. (Leigh)

On a more day-to-day basis, participants spoke extensively about their working hours and how they structured their week. Several of the participants described their ideal weeks as comprising of some regular, fixed work and some 
independent, more flexible activity. They explained how 'no week is ever the same' (Alice). However, some independent dancers aimed to maintain a sense of structure and consistency, or made decisions about times when they would stop working:

I did try to give myself some kind of routine, even if it was just "right I'll go for a run every Tuesday morning", "I'll make plans every Thursday evening", "I'll do my administration on a Friday". (Alice)

In terms of the hours that independent dancers worked, they varied from week to week, role to role. What was apparent was that within any of their different work contexts the participants worked very long hours and continued their various informal activities outside of these roles, undertaking administrative or supporting work to ensure they were prepared for future employment. This issue has been raised in past research that describes independent dancer's work as 'ever increasing' (Rouhiainen 2003, 298) and 'irregular' (Rouhiainen 2003, 314), and although some dance agencies have aimed to address these concerns providing training and advice for issues such as time management and organisation, there has been no formal data collected about the working hours of independent dancers. More longitudinal data needs to be gathered to build a more accurate picture of the working hours that independent dancers undertake.

The role of networks and relationships:

The participants recognised that establishing networks and building relationships with other independent artists was important for enabling them to find and manage their work. Some cited geographical location as an important factor, with London being a particularly preferable place to work:

I feel in London it takes maybe a bit longer but once I'm there, up there, as a choreographer and people know my name it will be easier to do everything. (Robert)

However others contrasted this by explaining that they were able to build effective professional networks in other cities or smaller communities:

Once I moved home [Derbyshire] and started to get back into contact with people involved in dance regionally and involved in community dance and dance in education, I started to realise that actually, there were lots of great things going on in the arts. (Alice)

In both instances local networks were a crucial element of the participants' employment. Existing literature suggests that regionally-based arts organisation or dance agencies support such networks and provide 'specialist and coherent year-round programme[s], offering opportunities to share practice and exchange information, to deepen enquiry, enhance skills and acquire new knowledge' (Clarke 1997). Such support is a vital part of independent dancers careers and therefore dancers should feel supported regardless of their location. It is important that those entering the profession are aware of other regionally based support systems and do not feel that they must live in London in order to forge successful careers. 
Several participants commented upon how the networks they established were important for finding new work. This often happened through casual communication and word of mouth:

I get all my work and most of my enjoyment as well, just from talking to people, finding out what's going on. (Mary)

Many of the participants felt that these kinds of relationships were more valuable in terms of finding future employment than attending formal auditions or interviews, as it allowed them to get a better understanding of the work they were potentially undertaking. It also provided potential employers with an insight into the participant's practice and personality that they felt could not be expressed through a $\mathrm{CV}$.

As well as building networks to seek employment, the participants also discussed how they developed working relationships to support them in other ways. Several participants described some kind of mentorship that had helped develop their careers. In some instances this was through a formal mentorship programme set up by organisations or individual practitioners looking to support others, but in most cases it involved dancers informally seeking advice or support from people they were working for and felt comfortable with:

It's recognizing someone that I feel I have an affinity with and then seeking out their opinion on certain things when I can. (Jenny)

In the past, the Independent Dance Review Report called for more structure and distinction to ensure mentorships are mutually beneficial and effective (Clarke, Gibson 1998). Although this argument is well founded and could improve development opportunities within the industry, the findings from this study also demonstrate the importance of informal mentorship.

As well as building relationships with more advance practitioners, participants found support from their peers highly valuable, explaining that being around dancers in a similar position could be just as beneficial as seeking advice from someone with more experience. The findings further echo Farrer's work on how dancers learn tacitly from peers that they trust and share mutual cares and concerns with (2014). These relationships appeared to be vital in combatting the sense of isolation or loneliness that some participants described when working independently:

I think it's bringing those networks of people around you that can support your career. I think that's the most important, you know even though I work independently, on my own a lot, the people I ring are in the same boat as me. And they're all artists; they're all dancers actually. And they get it. So I don't feel on my own. (Jane)

Although none of the participants explicitly described sharing resources Jane did state that she would come together with other artists to 'play' indicating that this idea, proposed by Clarke and Gibson (1998), is developing among the independent dance community through the sharing of practice. 
Finally, some participants spoke about the importance of their social or family networks. Some commented generally upon how relationships informed their approach to work and others had made clear decisions about their careers in response to their home lives:

I did make a pact when I was 26, 27-I am not working weekends anymore, this is ridiculous, I need to see people and have a life. (Jeanne)

As well as shaping the way the participants engaged with their work, the support that friends and families provided also extended to particular skills that were helpful for their careers. Some participants spoke about instances where friends or family members had advised them on issues such as finance, business and organisational skills. Again, this concern has been raised in the past by Clarke and Gibson who highlighted that independent artists 'acquire many complementary skills' $(1998,15)$ in order to succeed in the sector. The findings from this study together with previous research indicate that because participants were relying on informal and social networks to supply such skills they may not be provided sufficiently by the sector or by dance training (Aujla, Farrer 2015; Clarke, Gibson 1998).

\section{How do independent dancers' careers change and develop over time?}

This theme was created by comparing the way participants at different stages of their careers described and reflected upon their work. Although participants did not themselves identify their careers as having distinct stages, the results generally indicated three categories: early, mid and late stages. The findings were significant because this is a theme that has never before been addressed within academic literature or industry reports.

\section{Early stages:}

When reflecting back on the beginning of their careers, many of the more experienced participants expressed that they had felt unprepared for entering the professional sector after their training for various reasons:

I was kind of learning as I went what I wanted to do ... I think as a student you're kind of in a bubble at any institution that you are at... I don't think I ever knew what to expect. (Leigh)

It was noted, however, that some of the participants who had graduated more recently felt that their training did help to prepare them, and that it provided some opportunities for transitioning into the profession:

While I was at University I was already making my own work alongside and things like that, and going to auditions... a choreographer came into Uni to look for dancers so I got like my first job from an audition that was held at Uni ... so when I left I already had quite a lot of experience (Sally) 
Either way, when describing the early periods of their careers, most of the participants said that they were open to as many roles as possible and were 'applying for everything' to ensure they found work. This related to a common problem that participants faced in the early stages of their careers, which was managing their time. Because the dancers' main priority appeared to be having work, regardless of what it entailed, many found it difficult to set boundaries, and prioritise roles:

I want to get a more regular pattern perhaps ... I find it really hard to switch off. (Jenny)

One of the reasons for this was the pressure participants felt from others to appear successful . Many compared themselves to peers undertaking more regular work in other sectors or felt that their families and friends did not understand their freelance position:

There's a lot of people I don't think understand it, like my nan or some of my friends and they're like, 'Oh so you, like are you all sorted now' and I'm like, 'I'm never going to be completely sorted', you know? So yeah, I guess people might not think that you're working as hard as you are and appreciate it. (Jenny)

As a result, some participants felt 'guilty' if they were not seen to be actively working all the time and thus felt pressure to take on any kind of work they could.

Mid stages:


engagement with work shifted. Many expressed that they felt more confident with the work they were doing, and felt more valued as practitioners:

I think I'm just more relaxed about it now... I'm more confident when I'm writing applications and cover letters and my network range is a lot bigger so yeah it's become easier. (Sally)

As the participants became more confident with their roles, they also appeared to develop more of a sense of identity about who they were as artists. They felt clearer about the kind of work they wanted to do and why:

I wouldn't work for anybody now. I am going to be really, really selective. (Stephanie)

The dancers also appeared to develop more of a sense of ownership over their work:

I'm not so interested in performing work for other people where I feel like the work itself doesn't have a lot of integrity or where I feel very much like a kind of tool... it's not so interesting to me to simply replicate, necessarily, every time I do performance work. (Louise)

The sense of confidence and ownership was clearly a positive development within the participants' careers. However, with increased success and experience came new pressures and concerns. Some of the dancers commented that as they got more work they found it increasingly difficult to manage their time and keep 
up their networking and self-development opportunities. They also felt increased pressure on them to maintain the same level of success, often in the eyes of other people:

I got funding for a piece, now I'm worried that I've got to kind of up the bar ... and I feel like the pressure's on because, like, right now I don't have an idea to make another piece (Sally)

Some dancers felt that this also led to them feeling 'pigeon holed' (Alice). As they established success in one area of their practice it sometimes led to employers assuming this was their sole skill or interest. This seemed to be particularly prevalent among emerging practitioners who initially engaged largely in teaching work, but still wanted to pursue performance or choreographic roles.

Finally, some of the dancers commented that as they moved on with their careers they began to notice physical changes to their bodies, and some had to deal with injuries for the first time. Although these dancers were still in the mid stages of their careers as a whole, they appeared to be very aware of how their age could potentially be perceived as impacting their physical ability. Some commented on how they had to compete with younger dancers and demonstrate their ability in a new way:

I need to be able to bang out those five minute planks and those press-ups and whatever else and show that I might be older, but I am very, very capable of having the right stamina for the piece. (Alice)

Late stages:

As independent dancers moved into the later stages of their careers their engagement with their role appeared to develop again, often guided by personal circumstances and a more reflexive understanding of their career. Many of the participants felt more content and at ease about their work; after having initial success, they now had increased confidence in their ability and a greater sense of direction and autonomy that appeared to relieve some of the pressure that those in the early and mid stages of their careers experienced. Generally, age was considered a positive factor in these participants' careers and developing their experiences and reputation was perceived to increase their employability:

When I first got funding from the Arts Council there was a bit of pressure to prove myself. Maybe that's about being younger as well and feeling accepted by the arts world I think, accepted by these people. I feel like now I'm at the point where actually I judge myself by the people that I care about. (Jeanne)

Many of the more experienced participants such as Jane, Aiden, Anne and Robert had begun their careers as performers and moved into developing their own choreographic work as they became more established. The urge to work as a choreographer corresponded with a general desire that more experienced dancers developed to have increased control, ownership and autonomy over their work. In some instances this related to how they wanted to develop their own artistic practice: 
Now I feel a responsibility to really understand why I'm doing it, and for it to really say something (Jeanne)

In other examples, this desire for greater control related to how participants wanted to impact and benefit others engaging with the sector:

I'd love to own an arts centre, which doesn't just cater for dance but a lot more, working with different artists, poets and sculptors and creating platforms so that work can be shown, of course with the emphasis on dance. I think that's what I'd love to move more into. (Jane)

As well as the participants experiencing a shift in the way they engaged with their work, there was also a change in how they valued their home lives. Whereas many of the participants in the early stages of their careers expressed a feeling that they needed to commit completely to their careers and be prepared to do anything for it, as dancers' careers developed and they were able to sustain paid work, their priorities often changed alongside changes in life circumstances:

I think when I was younger my work and my job defined who I was. And it definitely still does... but I definitely respect my family time and being that person. (Jeanne)

In relation to the notion of prioritising, many of the participants who were in the mid or later stages of their careers commented on having children and how this would affect their work. Issues raised included: the logistical implications of working freelance around a child's needs; financial implications in relation to how companies supported dancers who had children; and the physical effects on their bodies. As a result of these challenges, some participants expressed a sense of concern or guilt about how they would be able to sustain and manage their careers while raising a child:

The baby thing is the biggest thing I think. ... How do I justify not being with my child, so like I go and do a professional class in the morning - I mean it's not important what other people think, but for a lot of people not in the dance world that seems like a frivolous hobby. (Stephanie)

Some participants had strategies to focus more on educational work or stop touring in order to allow themselves to continue careers in the sector while raising children, while others recognised that their priorities might change altogether when they had children:

I might want to choreograph children's work or realise I don't want to dance anymore, I want to volunteer... (Anne)

It is evident that for independent dancers establishing good home lives and feeling able to have children whilst maintaining their career in some form is a concern. As a broad subject area, gender, family life and freelance work has been heavily researched in related domains (Annink, den Dulk 2012; Baines, Gelder 2003; Baines, Wheelock, Gelder 2003; Hilbrecht, Lero 2014), however there is very little academic research (Cull, 2014) that addresses these issues in relation to the independent dance sector. At the time of interview none of the participants had children, however many chose to discuss this issue when asked about how 
they envisaged their careers progressing. The study demonstrates, therefore, the need for a further, longitudinal research that could explore this area on more detail.

In general the findings from this theme demonstrate how, although there are not explicitly defined career trajectories for independent dancers (Clarke, Gibson 1998), participants do develop a sense of progression throughout their careers. The sense of autonomy, freedom and control that dancers experience by working independently is an important motivating factor (Aujla, Farrer 2015). As such, it could be suggested that some dancers were motivated to develop their careers in relation to increasingly autonomous roles such as project management and choreography. It must be noted however that such autonomy was also facilitated by the participants finding more financial and social stability through increased employment and the support of partners or family over time. It is also likely that increased experience, knowledge and confidence enabled dancers to make informed decisions as their careers progressed (Aujla, Farrer 2015).

\section{How do independent dancers understand success?}

This theme was created from questions about how the participants defined success for themselves and in relation to others. They were asked about their future career aims and their wider views about the industry.

Due the multifaceted nature of their work, when asked how they would define success as an independent dancer the participants gave a range of responses and often articulated success in complex and multiple ways depending on their career stage. One measure that was raised by many of the participants - particularly those in the early stages - was 'having work'. Although most participants expressed that they were not financially motivated, they were aware that a key part of building a successful career was 'being able to support yourself' (Jenny). Most of the participants noted how difficult it could be to sustain work in the dance industry so felt like they were succeeding if they were able to maintain regular employment:

I think for me if I'm working then that is already a success, because there are a lot of dancers who are not working. Part of the difficulty is finding work, so I've always felt very lucky and in some ways successful that I have always been working. (Anne)

Further to the success of having regular work was the idea that dancers would be successful if they were able to make decisions about what that work was, something that developed as the participant's careers went on. There was often a sense that dancers wanted to 'tick things off' such as working with particular companies or choreographers, performing in particular theatres, performing overseas and writing successful funding bids. Interestingly, these measures of success were sometimes problematic for dancers if they felt they were not able to achieve them, or if the reality of a job did not live up to the participant's expectations: 
When I first got the job, it was like "wow" this was a massive tick off my ambition list. Fantastic! And it was a great experience in some ways, but then in other ways it made me realise actually it wasn't what I wanted to do. (Anne)

This kind of experience could be influenced by what Pauline Tambling describes as a split between 'superstar' artists, and 'low paid practitioners' (2015, p.11). The hierarchical divide that appears to exist within the dance industry means that less experienced dance artists often strive to work in contexts that they perceive as being more successful without necessarily having an accurate understanding of what the work will be like.

Many of the participants reported measures of success that related to their personal needs and development. Feeling fulfilled in what they did was a key factor, and many dancers described their work as enjoyable, making them feel 'inspired', 'happy' and 'interested'. Some participants discussed this in relation to the financial instability often associated with the work and expressed that their passion for the job outweighed any financial success. Although many of the success measures that participants cited were intrinsic in nature, some of the participants in the later stages of their careers felt that they wanted to leave some kind of legacy and have an impact on others:

Leaving a legacy that increases not only your reputation but the reputation of dance practice... You help create opportunities to network, share resources, share experiences, support each other and find ways of acknowledging what you've done in some ways' (Louise).

Interestingly, it appeared that participants felt they could achieve this kind of fulfilment most easily by taking on leadership roles such as choreography and project management. Several participants spoke about how they felt pressure to pursue this kind of work in order to progress their careers:

I find it hard to know what I would want funding for, because at the minute I still want to dance for other people more than choreograph myself and I find that it's hard to think you're an independent dance artist when you actually want to dance on project based stuff, for other people. I suppose you could apply for funding as a collective, and get choreographers in. (Leigh)

Despite Clarke and Gibson calling for hierarchies and career ladders to be dismantled (1998), this quote demonstrates how particular attitudes and perceptions can inform how the sector values different roles. This concern has been raised particularly in relation to choreography by Farrer (2014) and Roche (2009) who both argue that the dancer's contribution to choreographic practice should be recognised and valued more. The lack of recognition that Farrer (2014) and Roche (2009) highlight could be a reason that the participants in this study felt pushed into moving beyond working for others.

Overall, the participants appeared to be aware that they measured success in more than one way, and that in some instances these successes could contradict each other, or change over time. Battling with some of these contradictions is an issue noted by Clarke who commented on how independent dancers' artistic 
practices can easily become 'side-lined to income generation' (1997). There was a general consensus that, because of the varied and unpredictable nature of independent dancers' work, there were no predetermined measures of success or set goals that all participants would want to achieve. Most notably, dancers strove to continue developing. For less experienced dancers this appeared to cause some anxiety, as one participant claimed:

It feels like there's something unobtainable to keep working towards (Leigh).

However, those who were further in their careers were more reflective, and able to find success and fulfilment in different ways:

It's about being with yourself in the moment and that being your success you know? Rather than this constant striving of, if I get this job, if I work with this choreographer, then I've made it you know... Every day whoever I'm working with is the success and it's to be made successful. (Jeanne)

\section{IMPLICATIONS AND CONCLUSION}

The issues raised in this study suggest that over the last 20 years the independent dance sector has grown significantly, yet those working in the sector are still facing similar concerns and challenges to those described in the Independent Dance Review Report in 1998. It emerged that the dancers who took part in the study engaged in varied and complex work, and it was evident that they shared similar experiences and perceptions at particular stages of their careers. There is a growing body of academic research addressing concerns such as how psychological factors help dancers to succeed in the independent sector (Aujla, Farrer 2015) or how independent dancers engage artistically with the independent dance sector (Roche 2015). However there remains very little documentation of the work independent dancers do on a day-to-day basis and, as a result, there has been very little change in the way they are supported. Increased knowledge about the sector could allow educators, arts organisations and funders to help better prepare and support those working in the independent dance sector. Furthermore, by developing discourse and dialogue about this kind of role, those working in the sector can create better networks and relationships to support each other and share knowledge, resources and experiences.

University of Bedfordshire

\section{REFERENCES}

Annink, Anne and den Dulk, Laura. (2012). Autonomy: The panacea for selfemployed women's work-life balance? Community, Work \& Family. 15, 383-402. doi: 10.1080/13668803.2012.723901.

Aujla, Imogen and Farrer, Rachel. (2015). The role of psychological factors in the career of the independent dancer. Frontiers in Psychology. doi: 10.3389/fpsyg.2015.01688. 
Baines, Susan and Gelder, Ulrike. (2003). What is family friendly about the workplace in the home? The case of self-employed parents and their children. New Technology, Work and Employment. 18, 223-234. doi: 10.1111/1468-005X.00123.

Baines, Susan, Wheelock, Jane and Gelder, Ulrike. (2003) Riding the roller coaster: Family life and self-employment. Bristol: The Policy Press.

Bannerman, Christopher and McLaughlin, Cahal. (2009). Collaborative ethics in Practice as Research, in Allegue, L., Jones, S., Kershaw, B. and Piccini, A. (eds) Practice as Research: in Performance and Screen. (Basingstoke: Palgrave Macmillan).

Burns, Susanne and Harrison, Sue. (2009) Dance Mapping: A window on dance 2004-2008 (London: Arts Council England).

Butterworth, Jo. (2009). Too Many Cooks? A Framework for Dance Making and Devising, in Butterworth, J. and Wildschut, L. (eds) Contemporary Chorography: A Critical Reader. (London, New York: Routledge).

Charmaz, Cathy. (2006) Constructing grounded theory: A practical guide through qualitative analysis (London: Sage Publications).

Clarke, Gill. (1997). Supporting, stimulating, sustaining. Edited by Ian Bramley. Accessed August 24, 2015. http://www.independentdance.co.uk/wp-content/uploads/2010/11/ Supporting:StimulatingSustaining.pdf

Clarke, Gill and Gibson, Rachel. (1998) Independent dance review report (London: Arts Council England).

Creswell, John, Wand Miller, Dana, L. (2000) 'Determining validity in qualitative inquiry'. Theory into practice. (39) 3: 124-130.

Cull, M. (2014) Gender inequality in contemporary dance in the United Kingdom unpublished MA. dissertation (University of Chichester).

Hawksly, Sue. (2012). 'Dancing to an understanding of embodiment', unpublished $\mathrm{PhD}$. dissertation (Edinburgh: The University of Edinburgh).

Hilbrecht, Margo and Lero, Donna S., (2014). Self-employment and family life: constructing work-life balance when you're 'always on'. Community, Work \& Family. 17, 20-42. doi. org/10.1080/13668803.2013.862214.

Patton, Michael. Q. (2002) Qualitative evaluation and research methods (Thousand Oaks, CA: Sage).

Roche, Jenifer. (2009) Multiplicity, embodiment and the Contemporary dancer: Moving identities (Hampshire: Palgrave Macmillan).

Roche, Jennifer. (2009) 'Moving identities: Multiplicity, embodiment and the contemporary dancer', unpublished $\mathrm{PhD}$. dissertation (Roehampton: Roehampton University).

Rouhiainen, Leena. (2003) 'Living Transformative Lives: Finnish Freelance Dance Artists Brought into Dialogue with Merleau-Ponty's Phenomenology', unpublished PhD. dissertation (Acta Scenica).

Rubidge, Sarah. (1993) 'Gill Clarke: Dancer and campaigner'. Dance Theatre Fournal. 11 (1): 6-8, 52-55.

Tambling, Pauline. (2015). 'What are the future employment opportunities for dance?' Animated March 13: 10-12. 


\section{Your short guide to the EUP Journals Blog http://euppublishingblog.com/}

A forum for discussions relating to Edinburgh University Press Journals

\section{The primary goal of the EUP Journals Blog}

To aid discovery of authors, articles, research, multimedia and reviews published in Journals, and as a consequence contribute to increasing traffic, usage and citations of journal content.

\section{Audience}

Blog posts are written for an educated, popular and academic audience within EUP Journals' publishing fields.

\section{Content criteria - your ideas for posts}

We prioritize posts that will feature highly in search rankings, that are shareable and that will drive readers to your article on the EUP site.

\section{Word count, style, and formatting}

- Flexible length, however typical posts range 70-600 words.

- Related images and media files are encouraged.

- No heavy restrictions to the style or format of the post, but it should best reflect the content and topic discussed.

\section{Linking policy}

- $\quad$ Links to external blogs and websites that are related to the author, subject matter and to EUP publishing fields are encouraged, e.g.to related blog posts

\section{Submit your post}

Submit to ruth.allison@eup.ed.ac.uk

If you'd like to be a regular contributor, then we can set you up as an author so you can create, edit, publish, and delete your own posts, as well as upload files and images.

\section{Republishing/repurposing}

Posts may be re-used and re-purposed on other websites and blogs, but a minimum 2 week waiting period is suggested, and an acknowledgement and link to the original post on the EUP blog is requested.

\section{Items to accompany post}

- A short biography (ideally 25 words or less, but up to 40 words)

- A photo/headshot image of the author(s) if possible.

- Any relevant, thematic images or accompanying media (podcasts, video, graphics and photographs), provided copyright and permission to republish has been obtained.

- Files should be high resolution and a maximum of $1 \mathrm{~GB}$

- Permitted file types: jpg, jpeg, png, gif, pdf, doc, ppt, odt, pptx, docx, pps, ppsx, xls, xlsx, key, mp3, m4a, wav, ogg, zip, ogv, mp4, m4v, mov, wmv, avi, mpg, 3gp, $3 g 2$. 